\title{
ASSESSING THE GENETIC VARIABILITY IN EGG PRODUCTION AND EGG QUALITY TRAITS OF FOUR EGYPTIAN LOCAL STRAINS OF CHICKENS USING RAPD AND SSR TECHNIQUES
}

\author{
Lamiaa M. Radwan ${ }^{1}$, M.Y. Mahrous ${ }^{1}$ and M.E. EL-Denary ${ }^{2}$ \\ ${ }^{1}$ Poultry Production Department, Faculty of Agriculture, Ain Shams University, Cairo, Egypt, 2- Genetics \\ Department, Faculty of Agriculture, Tanta University, Tanta, Egypt \\ Corresponding author: lamia radwan@agr.asu.edu.eg
}

\begin{abstract}
SUMMARY
Local chicken strains are important, especially to the smallholder systems in developing countries. In this study we attempt to estimate the genetic characterization of some Egyptian local chicken strain/populations using SSR and RAPD markers. In four populations of Fayoumi, Gimmizah, Bandarah and Mandarah strains, egg production and quality parameters (egg number, weight, mass, eggshell strength, albumen weight, albumen percentage, Haugh units and yolk index) were recorded and evaluated for the first 3 months of the production cycle. Fayoumi eggs recorded a significant increase in the eggshell strength and yolk percentage when compared to other strains. On the other hand, Fayoumi hens recorded a significant decrease in egg production, egg weight and egg mass compared to Gimmizah, Bandarah and Mandarah ones. Yolk index showed a significant increase for Fayoumi eggs compared to all studied eggs strains. Moreover, albumen weight and albumen percentage recorded a significant increase for eggs of Bandarah and Mandarah compared to those of Fayoumi and Gimmizah strains. Six SSR and five RAPD primers were used to estimate genetic heterogeneity. Molecular marker analysis indicated that Bandarah and Mandarah showed a similarity of 60\% in one group, while Gimiezah's similarity only reached 53\%. On the other hand, Fayoumi was less similar to the other tested strains (about 40\%). Heterozygozity within each studied strain -based on allele frequency-was also studied. Fayoumi breed showed lower heterozygozity (0.23) than Gimieizah, Mandara and Bandara which showed 0.26, 0.30 and 0.31 heterozygote values respectively. So, we recommend that SSR technique is useful in establishing genetic relationship among the populations and in indicating the purity of the breeds.
\end{abstract}

Keyword: RAPD, SSR, genetics, Egyptian strains, production parameters

\section{INTRODUCTION}

Poultry production is an important livestock sector for supplying humans with animal protein. It is especially favorable to the smallholder systems in developing countries due to low capital investment and high cost efficiency. Egyptian local chicken strains are important, but the information on their genetics with respect to performance, adaptability, resistance, genetic variability and genetic relationships are little. Chicken are rich in genetic diversity and have a high recombination rates (Siegel et al., 2006). Molecular markers such as RAPD and SSR have so far proved to be useful in establishing genetic relationship among the livestock populations including poultry (Hillel et al., 1992). Different genetic marker systems have successfully been used in poultry for estimation of genetic characterization of chicken breeds and populations including RAPD (random amplified polymorphic DNA) (Singh and Sharma, 2002) and microsatellites (Kaiser et al., 2000 and Osman et al., 2006). Information on genetic relationship, both within and between the populations has several potential applications in breeding programs, such as selection of parents for crossing predicting the genetic gains and testing population genetic hypotheses. Most of the genetic studies demonstrated that epistatic effects have been increasingly recognized as important genetic factors in the inheritance of quantitative traits (Sheridan and Randall, 1977; Sheridan, 1980; Fairfull et al., 1985 and 1987 and Abou El-Ghar and Abdou, 2004).

Abou El-Ghar et al. (2011) had a framework of crossing Matrouh as a common chicken parent with different strains of chickens that was done to investigate the effect of single crossing on some productive traits; as a consequence of crossing Matrouh as a sire parent with Silver Montazah, Mandarah and Inshas developed strains of chicken. Abou El-Ghar et al. ( 2007) ; Ghanem et al. ( 2008) reported that egg production can be benefited by reducing age and increasing body weight at sexual maturity while increasing egg weight at different ages of production. Moreover, crossing Matrouh as a female parent with Silver Montazah, Mandarah and Inshas improved egg number and egg mass at different periods of laying (Ghanem et al., 2008). Genetic selection procedures for important economic traits may negatively impact the subsequent productive efficiency of breeds, for both meat and egg production (McGary et al., 2002). Estimation of genetic diversity within and between chicken populations as well as association between 
microsatellites and economic traits has been undertaken using such markers (Pandey et al., 2005; Chatterjee et al., 2008\&2010; Rajkumar et al., 2008 and Radwan et al., 2014). In this research, the role of the genetic diversity in improving some egg production and egg quality traits were studied for fours Egyptian local strains using six microsatellites (SSR) and five RAPD primers.

\section{MATERIALS AND METHODS}

This experiment was designed to study the genetic variability in some egg production and egg quality traits of three Egyptian developed strains (Gimmizah, bandara and mandara) and one pure local breed (Fayoumi). The farm work was carried out at El Takamoly Poultry Project, Fayoum, Egypt, while the lab work was done at the Dept. of Poultry Production, Faculty of Agriculture, Ain Shams University and the Dept. of Genetics, Faculty of Agriculture, Tanta University. The flocks after hatching used in this experiment were reared under the same environmental, managerial and hygienic conditions. They were housed in individual cages placed in an open-sided house. They were fed a laying diet containing $16.3 \% \mathrm{CP}$ and $2924 \mathrm{kcal}$ $\mathrm{ME} / \mathrm{kg}$. Feed and drinking water were offered to birds ad libitum, whereas conventional breeding and management procedures were applied throughout the experimental period which lasted up to 0 . weeks of age. The lighting schedule was maintained at 16 hours of light and 8 hours of darkness throughout the experiment.

\section{Production performance:}

Egg production (number and weight) was recorded for the first 3 months of the production cycle to calculate egg mass. To assess internal egg quality parameters, a total of 240 eggs were randomly collected from each strain at 35 weeks of age. The dimensions of eggs (width and length) were measured using a digital caliper to calculate shape index. Each egg was first weighed to the nearest $0.1 \mathrm{~g}$ and broken open. The height of albumen and yolk was measured using a micrometer mounted on a stand with a platform on which the liquid content was placed. Each egg yolk was separated from the albumen using a plastic egg separator, rolled on a tissue paper to a well to remove any adhering albumen and was then weighed. Albumen yield was determined by subtraction of the yolk and shell weight intact from the whole egg weight. The percentage of egg components (yolk, albumen and shell) was calculated as the ratio of egg component to egg weight multiplied by 100. Yolk index (yolk height/yolk diameter) was also calculated. Haugh units were calculated according to Stadelman et al. (1988). Eggshell was weighed to the nearest 0.01g; then its percentage was calculated.

\section{Genomic DNA isolation:}

Twelve blood samples were randomly collected from each strain into vacuum tubes containing EDTA and stored at $-20^{\circ} \mathrm{C}$. Genomic DNA was isolated from blood samples using AXYGEN kit (Axyprep TM) from Axygen Scientific, inc. USA Cat. No. APMN-BL-GDNA-50. DNA concentration was determined using spectrophotometer and the final concentration was adjusted up to $50 \mathrm{ng} / \mu \mathrm{l}$ for PCR analysis.

\section{Molecular marker analysis (SSR and RAPD):}

Genomic DNA of twelve individuals from each strain was used as a template for PCR which were carried out against six SSR and five RAPD primers. The codes, sequences and melting temperatures of these primers are shown in Table (1). PCR was performed in $25 \mu 1$ volumes containing $12 \mu \mathrm{l}$ of PCR Master mix 2x (CinnaGen/ Iran), $2 \mu$ l of each primer $(10 \mathrm{pmol} / \mu \mathrm{l}), 1 \mu \mathrm{l}$ genomic DNA $(50 \mathrm{ng} / \mu \mathrm{l})$ and $10 \mu 1$ sterile deionized water were added.

\section{PCR analysis:}

PCR reactions were achieved in thermal cycles (LongGene - MG96G / china) that were differently programmed for each of the primers. The initial denaturation temperature of the first cycle was $94 \mathrm{C}^{\circ}$ for $4 \mathrm{~min}$ for all primers. The next 30 cycles varied in temperature settings (for $1 \mathrm{~min}$ ) according to each primer. Final extension was $72 \mathrm{C}^{\circ}$ for $5 \mathrm{~min}$ for all primers.

PCR products (15 $\mu$ l of each reaction) and $100 \mathrm{bp}$ DNA ladder (Larova GmbH- Germany) as DNA size marker were resolved by electrophoresis on $2 \%$ agarose gel containing ethidium bromide for $90 \mathrm{~min}$. at 70 volt, visualized via UV transilluminator and then photographed. Molecular size of the amplified fragments separated on gels was measured by analyzing gel images with Gel Analyzer software package version 2010a.

\section{Statistical analysis:}

Data were subjected to a one-way ANOVA using GLM (SAS Institute, 2001) with strains as fixed effect.

The statistical model used in this study was as follows;

Yijk $=\mu+B_{i}+e_{i j}$

Where; $\mu=$ Overall mean, $B_{i}=$ strain effect and $e_{i j}=$ Experimental error.

\section{Microsatellite and RAPD data analysis:}

The amplified bands were scored for each microsatellite and RAPD marker based on the presence or absence of bands, generating a binary data matrix of 1 and 0 for each marker system. The data matrix was then analyzed using the PAST, ver. 1.90 (Hammer et al., 2001), Then was used to calculate the genetic similarity based on Jaccard's similarity coefficients. 
Table 1. Codes, sequences and annealing temperatures of the used primers

\begin{tabular}{|c|c|c|c|c|}
\hline $\begin{array}{l}\text { Primer } \\
\text { Name / }\end{array}$ & Primer sequence & $\begin{array}{c}\text { Annealing } \\
\text { temp. }\end{array}$ & $\begin{array}{c}\text { No of allele } \\
\text { expected }\end{array}$ & $\begin{array}{c}\text { Allele } \\
\text { size (bp) }\end{array}$ \\
\hline \multirow[t]{2}{*}{ ADL 115} & F (5- GGATGAGAAGAAAGGCA 3-) & $50^{\circ} \mathrm{C}$ & 5 & $85-500$ \\
\hline & R (5- CAATGGTGGTTCAGGTAATC $\left.3^{-}\right)$ & $56^{\circ} \mathrm{C}$ & & \\
\hline \multirow[t]{2}{*}{ ADL 209} & F (5- GGTTAGCTCCCTCCTTCCAG 3-) & $63^{\circ} \mathrm{C}$ & & \\
\hline & R $\left(5^{-}\right.$AAGGAAACAAAGAGAAATCC $\left.3^{-}\right)$ & $52^{\circ} \mathrm{C}$ & 4 & $150-300$ \\
\hline \multirow[t]{2}{*}{ ADL 231} & F (5- ACTATTAGCCTGGGGAGAGC $\left.3^{-}\right)$ & $60^{\circ} \mathrm{C}$ & & \\
\hline & $\mathrm{R}\left(5^{-}\right.$TCACTCCAGCTTGAGACAGG $\left.3^{-}\right)$ & $60^{\circ} \mathrm{C}$ & 5 & $100-670$ \\
\hline \multirow[t]{2}{*}{ APH 23} & F (5- GGATGAGAAGAAGAAAGGCA $\left.3^{-}\right)$ & $56^{\circ} \mathrm{C}$ & & \\
\hline & R ( $5^{-}$AAGGAAACAAAGAGAAATCC $\left.3^{-}\right)$ & $52^{\circ} \mathrm{C}$ & 6 & $95-270$ \\
\hline \multirow[t]{2}{*}{ APH 24} & F $\left(5^{-}\right.$GGATGAGAAGAAGAAAGGCA $\left.3^{-}\right)$ & $56^{\circ} \mathrm{C}$ & & \\
\hline & R (5- CAATGGTGGTTCAGGTAATC $\left.3^{-}\right)$ & $56^{\circ} \mathrm{C}$ & 5 & $100-490$ \\
\hline APH-09 & $\begin{array}{l}\mathrm{F}\left(5^{-} \text {GGATGTTGCCCCCACATATTT } 3^{-}\right) \\
\mathrm{R}\left(5^{-} \text {TTGCCTTGTTTATGAGCCATTA } 3^{-}\right)\end{array}$ & $\begin{array}{l}56^{\circ} \mathrm{C} \\
52^{\circ} \mathrm{C}\end{array}$ & 5 & $95-370$ \\
\hline OPA-01 & $5 \backslash$ CAGGCCCTTC 3\} $&{34^{\circ} \mathrm{C}} &{9} &{\begin{array}{l}220- \\
1700\end{array}} \\
{\hline \text { OPB-03 }} &{\text { 5\САТСССССТG 3\ }} &{34^{\circ} \mathrm{C}} &{11} &{\begin{array}{l}200- \\
2800\end{array}} \\
{\hline \text { OPB-14 }} &{\text { 5\ TCCGCTCTGG 3\} } &{34^{\circ} \mathrm{C}} &{8} &{\begin{array}{l}350- \\
1700\end{array}} \\
{\hline \text { OPG-01 }} &{5 \backslash \text { CTACGGAGGA 3\} } &{34^{\circ} \mathrm{C}} &{6} &{\begin{array}{c}290- \\
1500\end{array}} \\
{\hline \text { OPZ-01 }} &{\text { 5\TCTGTGCCAC 3\} } &{34^{\circ} \mathrm{C}} &{7} &{\begin{array}{l}290- \\
1650\end{array}} \\
\hline\end{array}$
\end{tabular}

Table 2. Means \pm SE of egg production characteristics for different Egyptian strains

\begin{tabular}{|c|c|c|c|c|c|}
\hline \multirow[t]{2}{*}{ Traits } & \multicolumn{4}{|c|}{ Strain } & \multirow[t]{2}{*}{$\begin{array}{c}\text { P- } \\
\text { Value }\end{array}$} \\
\hline & Fayoumi & Gimmizah & Bandarah & Mandarah & \\
\hline $\begin{array}{l}\text { Percent egg } \\
\text { production }\end{array}$ & $79.25 \pm 1.89^{\mathrm{b}}$ & $82.50 \pm 1.48^{\mathrm{ab}}$ & $85.45 \pm 1.90^{\mathrm{a}}$ & $80.48 \pm 1.76^{\mathrm{ab}}$ & 0.03 \\
\hline Egg mass (gm) & $3256.48 \pm 78.76^{b}$ & $3749.88 \pm 86.27^{\mathrm{a}}$ & $3599.81 \pm 93.92^{a}$ & $3608.56 \pm 105.60^{\mathrm{a}}$ & 0.002 \\
\hline Egg weight (gm) & $42.33 \pm 0.56^{\mathrm{b}}$ & $50.47 \pm 0.65^{\mathrm{a}}$ & $50.92 \pm 0.57^{\mathrm{a}}$ & $49.56 \pm 0.46^{\mathrm{a}}$ & 0.0001 \\
\hline
\end{tabular}

a,b values in the same row for each parameter with different superscripts are significantly different $(\mathrm{P}<0.05)$

\section{RESULTS AND DISCUSSION}

Table (2) shows egg production characteristics for the four different strains studied. The Fayoumi hens had a significant) $\mathrm{P}<0.05$ ) decrease in egg production, egg weight and egg mass when compared with the other strains (Gimmizah, Bandarah and Mandarah).

Table (3) shows the means \pm SE of egg quality characteristics for the Egyptian strains studied. The eggshell strength recorded a significant $(\mathrm{P}<0.05)$ increase for Fayumi hens (4.88) when compared with Gimmizah (4.10), Bandarah (4.37) and Mandarah (4.01) strains. Mandarah eggs recorded a significant decrease in Haugh units compared to Fayoumi, Gimmizah and Bandarah eggs. Yolk index showed a significant increase for Fayoumi (49.02) than Gimmizah (46.76), Bandarah (42.56) and Mandarah (41.66). Moreover, albumen weight and albumen percentage showed a significant increase for Bandarah (31.70g, 61.35\%) and Mandarah eggs $(32.47 \mathrm{~g}, 59.72 \%)$ when compared with Fayoumi (26.54g, 57.45\%), Gimmizah (25.55g, 52.84\%) ones.
Gimmizah and Mandarah eggs had a higher significant heavier yolk weight when compared with Fayoumi and Bandarah. Yolk percentage for Gimmizah eggs (37.08) showed a significant increase than Fayoumi (31.59), Bandarah (29.69) and Mandarah (30.52) ones.

Fathi et al. (2010) recorded that the Mandarah strain eggs had better shell strength and ultrastructural formation compared to Bandarah one; but no significant difference between those for internal egg quality properties. On the other hand, Gimmizah strain eggs represented higher significant values for egg weight, yolk index and albumen percentage when compared to Mandarah eggs (Afifi et al., 2010).

In the current study, SSR and RAPD techniques were used to determine the achieved genetic improvement for egg production traits in both developed strains and pure ones; also, similarity and the degree of heterozygousity were measured.

Genetic variability estimates for each strain are summarized in Table (4). A total of 71 alleles were observed at the 11 loci in 48 individuals from 4 
chicken strains. The number of alleles observed across the microsatellite loci studied varied from 4 (ADL209) to 6 (APH23) with an overall mean of 5.00 , while the corresponding values recorded when using the RAPD markers varied from 6 (OPG-01) to 11(OPB-03) with an overall mean of 8.20.

To estimate similarity between the four different populations (Fayoumi, Gimmizah, Bandarah and Mandarah); genetic distance between the populations was calculated based on band frequency of all the eleven primers used the PAST program; version 1.90 based on Jaccard's similarity coefficients.

Data in Figure (1) indicate that Bandarah and Mandarah showed similarity of $60 \%$ in one group, while Gimiezah had a 53\% similarity with them. On the other hand, Fayoumi was less similar to the other tested strains (about 40\%) and can be seen as a separate group.

Table 3. Means \pm SE of egg quality characteristics for different Egyptian strains

\begin{tabular}{|c|c|c|c|c|c|}
\hline \multirow{2}{*}{ Traits } & \multicolumn{4}{|c|}{ Strain } & \multirow{2}{*}{ P- Value } \\
\hline & Fayoumi & Gimmizah & Bandarah & Mandarah & \\
\hline Hugh unit & $91.01 \pm 1.03^{\mathrm{a}}$ & $90.70 \pm 0.58^{\mathrm{a}}$ & $90.70 \pm 0.58^{\mathrm{a}}$ & $81.60 \pm 0.80^{b}$ & 0.0001 \\
\hline Yolk index & $49.02 \pm 0.65^{\mathrm{a}}$ & $46.76 \pm 0.76^{\mathrm{b}}$ & $42.56 \pm 0.52^{c}$ & $41.66 \pm 0.39^{c}$ & 0.0001 \\
\hline Albumin weight & $26.54 \pm 0.46^{\mathrm{b}}$ & $25.55 \pm 0.71^{\mathrm{b}}$ & $31.70 \pm 0.49^{\mathrm{a}}$ & $32.47 \pm 0.49^{\mathrm{a}}$ & 0.0001 \\
\hline Albumin percentage & $57.45 \pm 0.57^{\mathrm{b}}$ & $52.84 \pm 1.16^{\mathrm{c}}$ & $61.35 \pm 0.36^{\mathrm{a}}$ & $59.72 \pm 0.49^{\mathrm{a}}$ & 0.0001 \\
\hline Yolk weight & $14.59 \pm 0.27^{\mathrm{c}}$ & $17.77 \pm 0.49^{\mathrm{a}}$ & $15.30 \pm 0.20^{c}$ & $16.52 \pm 0.15^{\mathrm{b}}$ & 0.0001 \\
\hline Yolk percentage & $31.59 \pm 0.47^{\mathrm{a}}$ & $37.08 \pm 1.19^{\mathrm{b}}$ & $29.69 \pm 0.34^{\mathrm{b}}$ & $30.52 \pm 0.42^{\mathrm{b}}$ & 0.0001 \\
\hline Shell weight & $4.55 \pm 0.25^{\mathrm{b}}$ & $4.87 \pm 0.11^{\mathrm{ab}}$ & $4.63 \pm 0.14^{\mathrm{b}}$ & $5.32 \pm 0.18^{\mathrm{a}}$ & 0.01 \\
\hline Shell percentage & $9.92 \pm 0.49^{\mathrm{ab}}$ & $10.21 \pm 0.13^{\mathrm{a}}$ & $8.97 \pm 0.25^{\mathrm{b}}$ & $9.65 \pm 0.31^{\mathrm{ab}}$ & 0.05 \\
\hline Egg weight & $45.75 \pm 0.70^{\mathrm{d}}$ & $48.19 \pm 0.59^{c}$ & $51.64 \pm 0.63^{\mathrm{b}}$ & $54.3^{\prime} \pm 0.69^{\mathrm{a}}$ & 0.0001 \\
\hline Shape index & $77.23 \pm 0.47$ & $77.91 \pm 0.82$ & $75.84 \pm 0.38$ & $76.52 \pm 0.50$ & NS \\
\hline Shell strength & $4.88 \pm 0.07^{\mathrm{a}}$ & $4.10 \pm 0.07^{\mathrm{c}}$ & $4.37 \pm 0.10^{\mathrm{b}}$ & $4.01 \pm 0.12^{\mathrm{c}}$ & 0.0001 \\
\hline
\end{tabular}

a,b,c values in the same row for each parameter with different superscripts are significantly different $(\mathrm{P}<0.05)$

Table 4. Measures of genetic variation in each of the studied Egyptian chicken strain

\begin{tabular}{|c|c|c|c|c|c|c|c|c|c|c|c|c|}
\hline \multirow{2}{*}{$\begin{array}{c}\text { chicken } \\
\text { strain }\end{array}$} & \multicolumn{11}{|c|}{ Locus } & \multirow{2}{*}{$\begin{array}{l}\text { Heterozygosity } \\
\text { within the } \\
\text { tested } \\
\text { population }\end{array}$} \\
\hline & 定 & 完完 & $\overrightarrow{\overline{2}} \bar{\imath}$ & 要 & $\frac{1}{2} 8$ & $\stackrel{T}{\frac{\pi}{\alpha}}$ & 仓े & $\frac{n}{0} \pm$ & ঠ) & की & $\sum_{0}^{1} \overline{0}$ & \\
\hline \multicolumn{12}{|c|}{ Observed No of alleles } & \multirow{4}{*}{0.23} \\
\hline \multirow[t]{3}{*}{ Fayoumi } & 4 & 3 & 4 & 4 & 5 & 5 & 5 & 4 & 4 & 5 & 9 & \\
\hline & \multicolumn{11}{|c|}{ range size (bp) } & \\
\hline & $\begin{array}{l}85- \\
500\end{array}$ & $\begin{array}{c}150- \\
300\end{array}$ & $\begin{array}{c}140- \\
670\end{array}$ & $\begin{array}{l}90- \\
270\end{array}$ & $\begin{array}{l}95- \\
370\end{array}$ & $\begin{array}{c}160- \\
490\end{array}$ & $\begin{array}{c}350- \\
950\end{array}$ & $\begin{array}{c}350- \\
600\end{array}$ & $\begin{array}{l}490- \\
1670\end{array}$ & $\begin{array}{l}320- \\
1400\end{array}$ & $\begin{array}{l}370- \\
1700\end{array}$ & \\
\hline \multirow{4}{*}{ Gimmizah } & & & & & Obse & ved $\mathrm{N}$ & of alle & & & & & \multirow{4}{*}{0.26} \\
\hline & 4 & 3 & 4 & 4 & 5 & 5 & 6 & 6 & 3 & 4 & 7 & \\
\hline & \multicolumn{11}{|c|}{ range size (bp) } & \\
\hline & $\begin{array}{l}85- \\
500\end{array}$ & $\begin{array}{c}150- \\
300\end{array}$ & $\begin{array}{c}140- \\
670\end{array}$ & $\begin{array}{l}90- \\
270\end{array}$ & $\begin{array}{l}95- \\
370\end{array}$ & $\begin{array}{c}160- \\
490\end{array}$ & $\begin{array}{l}350- \\
1190\end{array}$ & $\begin{array}{l}300- \\
1770\end{array}$ & $\begin{array}{l}490- \\
1670\end{array}$ & $\begin{array}{c}200- \\
900\end{array}$ & $\begin{array}{l}220- \\
1100\end{array}$ & \\
\hline \multirow{4}{*}{ Bandarah } & & & & & Obse & ved $\mathrm{N}$ & of alle & & & & & \multirow{4}{*}{0.31} \\
\hline & 4 & 3 & 4 & 4 & 5 & 5 & 5 & 3 & 4 & 8 & 7 & \\
\hline & \multicolumn{11}{|c|}{ range size (bp) } & \\
\hline & $\begin{array}{l}85- \\
500\end{array}$ & $\begin{array}{c}150- \\
300\end{array}$ & $\begin{array}{c}140- \\
670\end{array}$ & $\begin{array}{l}90- \\
270\end{array}$ & $\begin{array}{l}95- \\
370\end{array}$ & $\begin{array}{c}160- \\
490\end{array}$ & $\begin{array}{c}235- \\
995\end{array}$ & $\begin{array}{c}350- \\
600\end{array}$ & $\begin{array}{l}500- \\
1770\end{array}$ & $\begin{array}{l}200- \\
1100\end{array}$ & $\begin{array}{l}220- \\
1100\end{array}$ & \\
\hline \multirow{4}{*}{ Mandarah } & & & & & Obse & ved $\mathrm{N}$ & of allel & & & & & \multirow{4}{*}{0.30} \\
\hline & 5 & 3 & 4 & 4 & 5 & 5 & 5 & 3 & 4 & 6 & 7 & \\
\hline & \multicolumn{11}{|c|}{ range size (bp) } & \\
\hline & $\begin{array}{l}85- \\
500\end{array}$ & $\begin{array}{c}150- \\
300\end{array}$ & $\begin{array}{c}140- \\
670\end{array}$ & $\begin{array}{l}90- \\
270\end{array}$ & $\begin{array}{l}95- \\
370\end{array}$ & $\begin{array}{c}160- \\
490\end{array}$ & $\begin{array}{c}235- \\
995\end{array}$ & $\begin{array}{c}350- \\
600\end{array}$ & $\begin{array}{l}500- \\
1770\end{array}$ & $\begin{array}{l}200- \\
1700\end{array}$ & $\begin{array}{l}220- \\
1100\end{array}$ & \\
\hline
\end{tabular}




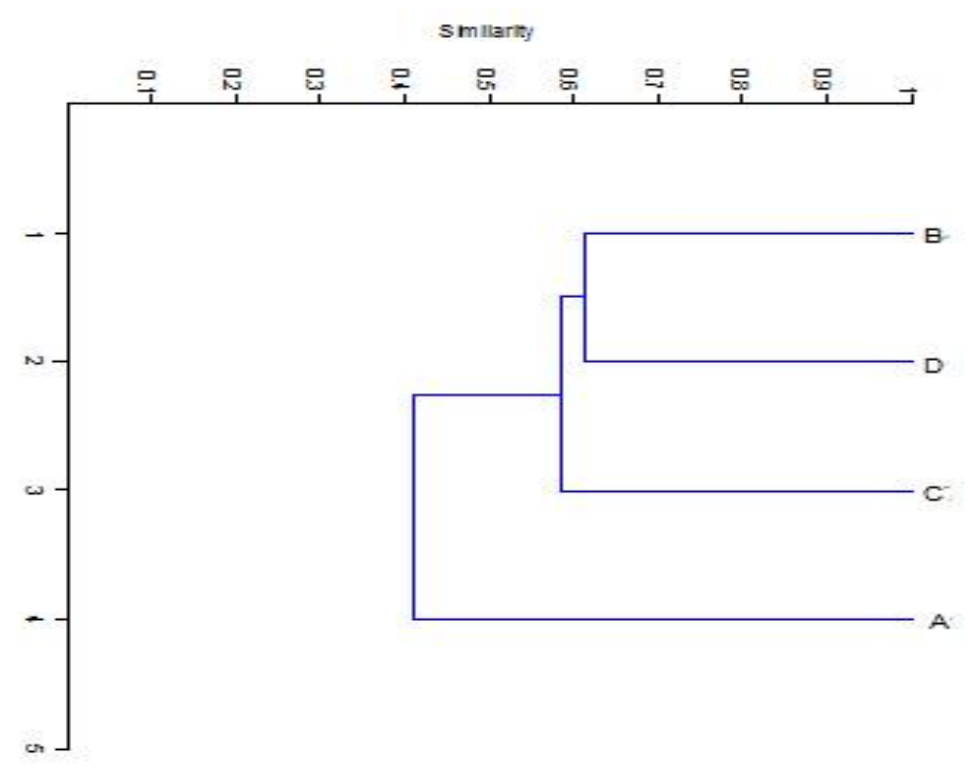

Fig. 1. Rooted neighbor joining (NJ) phylogenetic tree for the four studied Egyptian genotypes based on SSR makers. A, B, C and D are Fayoumi, Bandarah, Gimmizah and Mandarah, respectively

The Fayoumi breed had inserted into selection program to produce different Egyptian development strains, Fayoumi breed is considered as a grandparent to Gimmizah and Mandarah strains; while, Fayoumi breed had considered grand grand parent for Bandarah strain, the similarity between them reflected these relationships.

Table (4) shows the observed heterozygosity within each studied chicken genotype. The high heterozygosity estimate for most of the loci in the present study were probably due to existence of a large number of heterozygous alleles according to Chatterjee et al. (2010). Accordingly, the estimated haterozygosity for Fayoumi breed was lower $(0.23)$ than the other three strains (Gimieizah 0.26, Bandara 0.31 and Mandara 0.30 stains).

The current chicken genetic map contains at least 1,965 loci within 50 linkage groups, and it covers about 4,000 cM. The remaining loci are anonymous molecular DNA markers, including SSR, AFLP, ISSR, CR1 elements, and others (Emara and Kim, 2003).

The magnitude of additive effect is much greater than the dominance effect in some egg production traits (Szydlowski and Szwaczkowski, 2001 and Abou El-Ghar et al., 2009). However, epistatic effects were detected as a major mechanism of heterosis. Bauman (1959) proposed that epistasis is indicated if the performance of the progeny of a cross between a single cross and a tester deviates significantly from the average performance of the single crosses produced by crossing two inbred lines. Crow and Kimura (1970) reported that physiological epistasis contributes to additive, dominance and interaction genetic values and variances. Evidence supporting epistasis as a major mechanism of heterosis in chickens has been reported (Szydlowski and Szwaczkowski, 2001; Sheridan, 1980 and Fairfull et al., 1985 and 1987). The heterotic effects on egg production traits include variability produced by both dominance and epistasis (Fairfull et al., 1985, 1987 and Abou El-Ghar and Abdou, 2004). The objective of the current study was to achieve genetic improvement for egg production in crossbreds by applying crossbred methods between two local developed strains. The high heterozygosity estimate for most of the loci in the present study were probably due to the existence of a large number of heterozygous alleles according to Chatterjee et al. (2010). So the estimated haterozygosity for Fayoumi breed was lower $(0.23)$ than the other three strains (Gimmizah 0.26, Bandara 0.31and Mandara 0.30 stains), because the Fayoumi breed is considered as a pure Egyptian local breeds; while, the other strains (Gimmizah , Bandara and Mandara stains) produced cross breeding between a native strain and foreign strain Kosba and Abd El-Halim (2008).Continued genetic improvement of livestock is dependent on the fact that substantial genetic variation exists within individual breeds allowing them to respond to selection for different traits (Slavènaitè et al., 2004). The RAPD and SSR techniques examining population structure, diversity and gene flow in different (Fayoumi, Gimmizah, Bandara and Mandara) Egyptian local strain.

In the present study SSR and RAPD techniques were used to determine the appropriate number of alleles, range size and heterozygosity. This study ended with an important suggestion that chicken specific markers may be useful for examining the 
population structure and gene flow in a range of antedate. Although the detected genetic markers may have a known function and marked influence of trait variation. They can be used in combining information from a number of samples to draw a phylogenetic tree which considered as a good characterization of the studied population. The increasing numbers of available markers provides an elementary and powerful tool for better understanding of the genetic variance and population structure related to different Egyptian local strains

\section{CONCLUSION}

The Fayoumi breed showed low similarity and heterozygousity than Gimiezah, Bandarah and Mandarah Egyptian strains. SSR technique was used to determine the achieved genetic improvement for egg production traits in both developed strains and pure ones. The genetic findings that were made can be used in selection program for these egg production traits in early ages instead of remaining until they began their production.

\section{ACKNOWLEDGMENTS}

I am deeply grateful to Prof. Dr. A.M.R., Osman Professor of Anim. Prod. Inst., Agric. Research Center, Ministry of Agric, Egypt. He provided us with research facilities needed in this study.

\section{REFERENCES}

Abou El-Ghar R. Sh. and F.H. Abdou, 2004. Evaluation of genetic variance components based on the concept of generation means for some economic traits in chickens. Egyptian Poultry Science, 24: 687-699.

Abou El-Ghar R. Sh., H.M. Shalan ,H.H. Ghanem and O.M. Aly, 2009. Egg quality characteristics from some developed strains of chickens and their crosses. Egyptian Poultry Science, 29: 11731186.

Abou El-Ghar R.Sh., H.M. Shalan and H.H. Ghanem, 2007. Matrouh as a common parent in crossing with some local strains of chickens. Egyptian Poultry Science, 27: 805-815.

Abou El-Ghar R.Sh, O.M. Aly and H. H. Ghanem, 2011.Test of epistasis among triple crosses of matrouh with different strains of chickens. Egyptian Poultry Science, 31: 853-860.

Afifi Y.K., N.Y. Abou El-Ella, H.H Ghanem, 2010. Factors affecting hatching traits and post-hatch growth in two developed chicken strains. Egyptian Poultry Science, 30:157-177.

Bauman L. F., 1959. Evidence of non-allelic gene interaction in determining yield, ear height and kernel row number in Corn. Agron. Journal, 51:531-534.

Chatterjee R. N., R. P. Sharma, T. K. Bhattacharya, M. Niranjan and B. L. N.Reddy, 2010.
Microsatellite variability and its re- lationship with growth, egg production and immunocompetence traits in chickens. Biochemical Genetic, 48: 71-82.

Chatterjee R. N., R. P. Sharma, A. Mishra, M. Dange and T. K. Bhattacharya, 2008. Association of microsatellites with growth and immunocompetence traits in crossbred layer chicken. Journal Poultry Science, 45: 186-191.

Crow J. F. and M. Kimura, 1970. An Introduction to Population Genetics Theory. NewYork: Harper and Row 1970.

Emara M. G., and H. Kim. 2003. Genetic markers and their application in poultry breeding. Poultry Science, 82:952-7.

Fairfull R. W., R. S. Gowe and J. Nagai, 1985. Heterosis in White Leghorn strain crosses. Procceding British Poultry Breeders Roundtable (Edinburgh).

Fairfull R.W., R.S. Gowe and J. Nagai, 1987. Dominance and epistasis in heterosis of White Leghorn strain crosses. Canada Journal Animal Science, 67: 663-680.

Fathi M. M., Y. K. Afifi and S. A. El-Safty, 2010. Utlrastructural diversity of eggshell quality in some egyption local breeds of chicken. Egyptian Poultry Science, 30: 813-827.

Ghanem H. H., O. M. Aly and R. Sh. Abou El-Ghar, 2008. Matrouh as a common parent in crossing with some local strains of chickens: II- Heterosis, additive and maternal effects on some egg production traits. Egyptian Poultry Science, 28: 205-221.

Hammer Q., D. A. T. Harper and P. D. Ryan, 2001. PAST: Paleontological statistics software package for education and data analysis. Palaeontologia Electronica. 4(1): 9 pp. http://palaeoelectronica.org/2001_1/past/issue1_01.htm.

Hillel J., Dunnington E. A., and P. B. Siegel, 1992. DNA markers in poultry breeding and genetic analysis. Poultry Science Reverse 4: 169-186.

Kaiser M. G., N. Yonash,, A. Cahaner and S. J. Lamont, 2000. Microsatellite Polymorphism Between and Within Broiler Populations. Poultry Science. 79: 626-628.

Kosba, M.A. and H.A.H. Abd El-Halim, 2008. Evaluation of the Egyptian local strains OF chinks. Egyptian Poultry Science, 28: 1239-1251.

McGary S., I. Estevez, M. R. Bakst and D.L. Pollock, 2002. Phenotypic traits as reliable indicators of fertility in male broiler breeders. Poultry Science 81: $102-111$.

Osman, S. A. M., M. Sekino, A. Nishihata, Y. Kobayashi, W. Takenaka, K. Kinoshita, T. Ku wayama, M. Nishibori, Y. Yamamoto and M. Tsudzuki. 2006. The genetic variability and relationships of Japanese and foreign chicken assessed by microsatellite DNA profiling. AsianAustralian Journal Animal Science, 19: 13691378. 
Pandey A. K., D. Kumar, Sharma R., U. Sharma, Vijh R. K. and S. P. S. Ahlawat, 2005. Population structure and genetic bottleneck analysis of Ankleshwar poultry breed by microsatellite markers. Asian-Australian Journal Animal Science 18: 915-921.

Radwan L. M., A. E. El-Dlebshany and M. E. ELDENARY, 2014. Microsatellite genetic differentiation analysis and organic matrix of eggshell in the 16th generation of chickens selected for egg production traits. Egyptian Journal Animal Production 51: 49-55.

Rajkumar U., B. R. Gupta and A. R. Reddy, 2008. Genomic heterogeneity of chicken populations of India. Asian-Aust. Journal Animal Science, 21: 1710-1720.

SAS Institute, 2001. SAS/STAT User's Guide: Statistics. Ver.8.2, SAS Institute Inc.,Cary, NC.

Sheridan A.K. and M.C. Randall, 1977. Heterosis for egg production in White Leghorns-Australorp crosses. Brtish Poultry Science, 18: 69-77.

Sheridan A. K., 1980. A new explanation for egg production heterosis in crosses between White
Leghorns and Australorps. British Poultry Science, 21: 85-88.

Siegel P. B., J. B. Dodgson and L. Andersson, 2006. Progress from Chickens Genetics to the Chickens Genome. Invited reviews. Poultry Science, 85: 2050-2060.

Singh R. V. and D. Sharma, 2002. Within and between-strain genetic variability in White Leghorn population detectedthrough RAPD markers. British Poultry Science, 43:33-37.

Slavènaitė S., D. Butkauskas, A. Sruoga and E. Mozalienè, 2004. Comparative investigations of mallard duck (anas platyrhynchos) genomic DNA using chicken and duck specific microsatellite primers. veterinarija ir zootechnika, 48: 89-92.

Stadelman W. J., V. M. Olson, G. A. Shemwell and S. Pasch, 1988. Egg and Poultry Meat Processing. Ellis-Horwood Ltd, Chichester, UK.

Szydlowski M. and T. Szwaczkowski, 2001. Bayesian segregation analysis of production traits in two strains of laying chickens. Poultry Science, 80: $125-131$.

\section{تقييم التنوع الوراثى لصفات انتاج البض وجودة البيض فى اربع سلالات الاجاج المحلى المصرى بإستخدم RAPD


Egyptian J. Anim. Prod. (2015) 52(1):55-61

Issued by The Egyptian Society of Animal Production 